\title{
Economic and Social Injustices in Ghana's Military Regimes: an Investigation of Price Control Policies.
}

\author{
Seidu M. Alidu ${ }^{1}$,

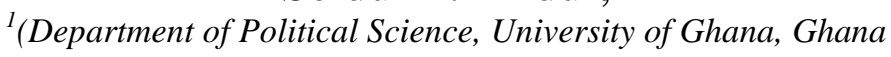

\begin{abstract}
The discourse of human rights has been dominated by civil and political rights much to the detriment of economic, social and cultural rights. However, both categories of rights are inalienable. Using mainly secondary source of data including a content analysis of the report of the Ghana National Reconciliation Commission and transcripts of the testimonies of some victims who testified before the Commission; this paper finds that majority of human rights violations were committed by state security institutions against victims professionally described as "general occupation" and the wealthy and influential in society. This magnitude of the violations, perpetrated against these victims never received adequate policy response. Though the National Reconciliation Commission was established to address past human rights violations in Ghana, it failed to holistically examine, and also recommend adequate policy for victims of economic and social injustices. In conclusion, this paper recommends that human rights violations of economic and social nature deserve same concerns and response in transitional periods since the former provides the context within which the latter occur.
\end{abstract}

Keywords: Africa, economic rights, human rights violations, transitional justice, truth commissions

\section{INTRODUCTION}

Ghana made history in the sub-Saharan African region by becoming the first country to break the shackles of colonialism. However, since independence on the $6^{\text {th }}$ of March 1957, its history has been characterized by tumultuous political changes and a glut of coup d'état, spanning from 1966 to 1991 with an intermittent constitutional governments, in which the military have seized power. Though the country has not experienced violent armed conflict ${ }^{\mathrm{i}}$ as it had happened in neighboring countries, a lot of human rights violations have been registered under these (i,e., the National Liberation Council; the National Redemption Council; the Supreme Military Council I\&II, the Armed Forces Revolutionary Council, and the Provisional National Defence Council) military regimes. These violations manifest in restrictions placed on press freedom, disproportionate and coercive use of state security institutions, and widespread arrest and torture of suspected 'enemies' of the state (Alidu, et. al, 2009). Two military regimes [the Armed Forces Revolutionary Council (AFRC) and the Provisional National Defense Council (PNDC)] stood out in the extensive use of repressive measures in dealing with citizens (NRC Report, 2004). Under both regimes mass arrests, abductions, torture, and the public flogging of people for the crime of selling commodities for more than the regime's controlled prices were common (Alidu, 2010). Using mainly secondary source of data including a content analysis of the report of the Ghana National Reconciliation Commission, transcripts of the testimonies of some victims who testified before the Commission and selected interviews of Commissioners of the Commission, the following questions have been answered: What was the nature of human rights abuses under military regimes in Ghana? How specific and what forms do economic and social human rights violations occurred? What were the consequences of such violations to the lives of the victims? What were the responses to these acts of violations?

\section{NATURE OF HUMAN Rights VIOLATIONS}

Generally, human right violations were targeted at people perceived to be regimes' "enemies" and not specifically against traders. The Ghanaian National Reconciliation Commission finds that a total of 8,686 victims suffered 12,517 violations (NRC Report, 2004), suggesting that some victims suffered more than one violation. It further indicates that a victim, on average, suffered about two violations and the minimum and maximum violations suffered were one and fifty-five respectively (NRC Report, 2004). Yet, violations against traders were seen as part of a general economic policy adopted by military regimes to keep prices of goods under control. Explaining this policy before the National Reconciliation Commission (NRC), the former Deputy Chairman and Spokesperson of the AFRC military regime, Osahene Boakye Gyan, notes "market forces...had run out of control" where "trade malpractices such as hoarding and overpricing of goods and services" became the order of the day. He maintains that "...predictably, the initial reaction to these inflated prices started with spontaneous looting, unauthorized arrest and spot punishment of suspects mainly traders and 
business people, and the destruction of market places like Makola as the symbol of market forces gone mad" (Boakye Gyan, 2003). Contrary, the NRC finds that "grave abuses were committed in the enforcement of price control laws. Goods were seized in circumstances in which it could not be said that there was hoarding or a sale above the control price. Soldiers fixed their own prices and used them as a pretext for plundering shops. Sometimes, goods in respect of which no maximum prices had been laid down were arbitrarily seized amidst beatings and other forms of ill treatment (NRC Report) ${ }^{\mathrm{ii}}$.

This economic policy fits very well into the AFRC and PNDC regimes' welfare or re-distribution policies. Significantly, the AFRC and the PNDC implemented a "one-man-one-house" economic policy; explaining that each man can only sleep in a house or drive in a car at a time and there was no need for anybody to owe more than a house or a car. This therefore led to unwarranted seizure of private properties for the purposes of bridging the yawning gap between the rich and the poor. Majority of human rights violations were committed against victims professionally described by the Commission as the "general occupation" category. This category, which includes bank managers, office managers and administrators, constitute $36.5 \%$ of total violations. The other category includes what it described as "miscellaneous" occupation category (30.9\%). Broadly, traders fell under the category described by the Commission as "owners" which recorded about $9.5 \%$ of the violations. It included business persons and small business owners. However, the greater percentage of violations (about 69\%) was committed against the wealthy and influential in the Ghanaian society and who owned large business. The table below indicates victims of human right violations by occupation.

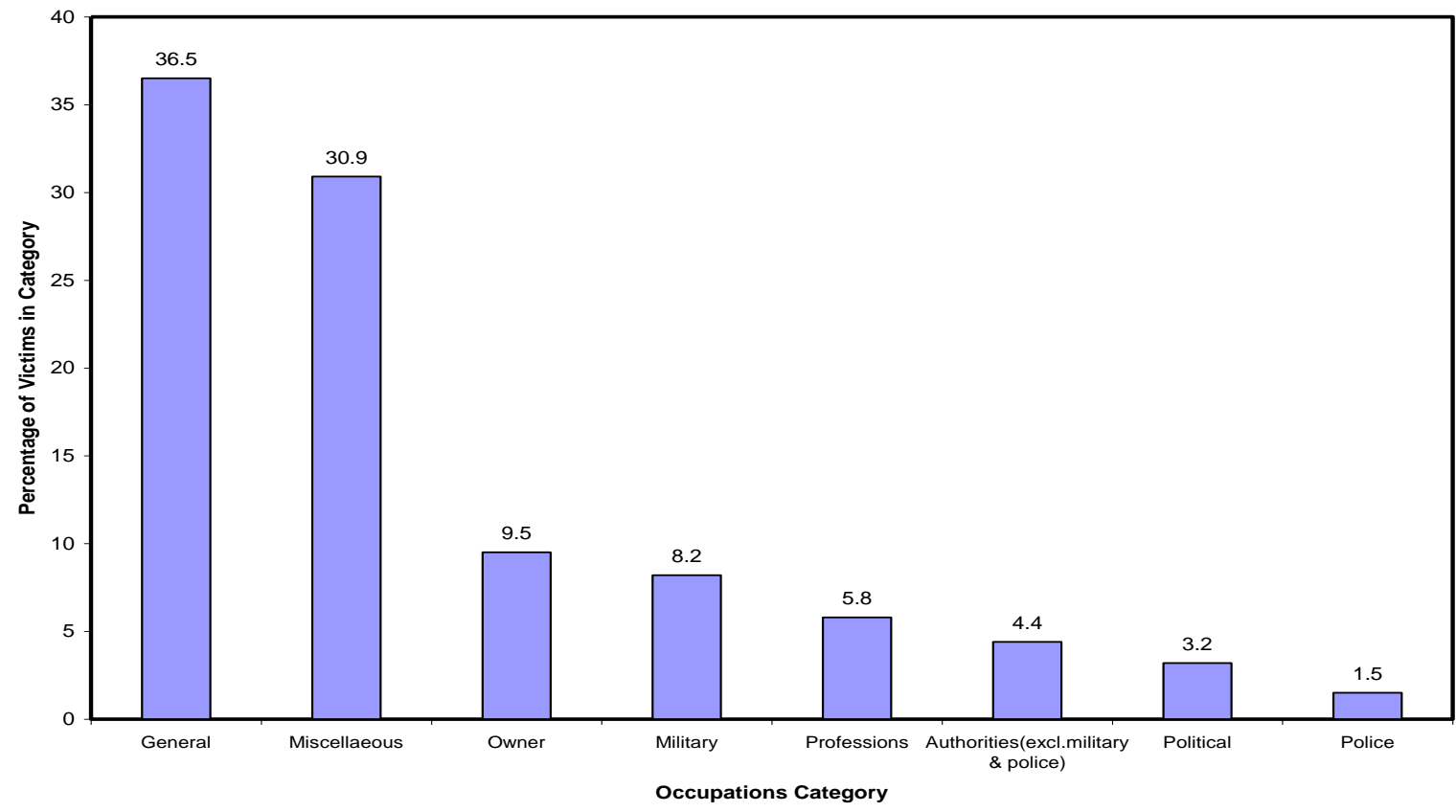

Figure 1: Human rights violations by professions (Source: Report of the National Reconciliation Commission, October 2004)

In figure two, economic crimes were recorded under two violation categories; "Dismissals" and "Property". Under the "Dismissal" category "Control Price" which is defined in this paper as a serious economic right violation is captured. This violation recorded $0 \%$ under the constitutional governments of the Convention Peoples' Party (CPP) and the Progress Party (PP); and 1.4\% under the Peoples' National Party (PNP) which is also a constitutional government. It also recorded $0 \%$ under the National Liberation Council (NLC) and the National Redemption Council (NRC) which were military regimes; and 2.8\% under the Supreme Military Council (SMC), 45.8\% under the Armed Forces Revolutionary Council (AFRC), 44.4\% under the PNDC that are also military regimes. This suggests that price control policies as violations of human rights of Ghanaians was an across board issue though it peaked in most military regimes and occurred in only one constitutional/civilian regime, the PNP. This is highly significant in the sense that the PNP government was sandwiched between two military regimes led by the same leader, Jerry John Rawlings, under whose regime this policy started. Under the "Property" category of violations, "extortion" and "forced sale" generally occurred under military regimes except during the PNP administration when forced sale recorded $2.4 \%$ and under the CPP when it recorded $0.6 \%$. 
Economic and Social Injustices in Ghana's Military Regimes: an Investigation of Price Control

\begin{tabular}{|c|c|c|c|c|c|c|c|c|c|c|c|}
\hline \multirow{2}{*}{$\begin{array}{l}\text { Violation } \\
\text { Category }\end{array}$} & \multirow{2}{*}{ Violation } & \multirow[b]{2}{*}{$\mathrm{CPP}$} & \multirow[b]{2}{*}{ NLC } & \multirow[b]{2}{*}{ PP } & \multirow[b]{2}{*}{$\mathrm{NRC}$} & \multirow[b]{2}{*}{$\mathrm{SMC}$} & \multirow[b]{2}{*}{ AFRC } & \multirow[b]{2}{*}{ PNP } & \multirow[b]{2}{*}{ PNDC } & \multirow[b]{2}{*}{ NONE } & \multirow[b]{2}{*}{ TOTAL } \\
\hline & & & & & & & & & & & \\
\hline \multirow{3}{*}{ Killing } & Disappearance & 9.7 & 0 & 0 & 0 & 0 & 9.7 & 0 & 80.6 & 0 & 100 \\
\hline & Execution Style Killing & 0 & 0 & 0 & 0 & 0 & 20.5 & 0 & 76.9 & 2.6 & 100 \\
\hline & Other Killing & 0.9 & 0.5 & 0.9 & 0.9 & 0.9 & 15.3 & 1.9 & 74 & 4.7 & 100 \\
\hline \multirow{9}{*}{ Mistreatm } & Abduction & 9.8 & 0.2 & 0.4 & 4 & 1.2 & 14.4 & 1.1 & 66.2 & 2.6 & 100 \\
\hline & Beating & 2.4 & 0.1 & 0.2 & 2.8 & 1.1 & 23.6 & 0.9 & 63.8 & 5.2 & 100 \\
\hline & Detention & 10.6 & 0.4 & 0.3 & 4.1 & 1.4 & 11.1 & 1.2 & 69.4 & 1.6 & 100 \\
\hline & Forced Displacement & 19.6 & 0.4 & 0 & 0.4 & 0.4 & 9.8 & 2.4 & 65.7 & 1.2 & 100 \\
\hline & Psychological Torture & 0.8 & 0 & 0 & 1.7 & 0 & 24.6 & 0 & 72.9 & 0 & 100 \\
\hline & Specified Torture & 2 & 0.2 & 0 & 10.5 & 0.5 & 26 & 1 & 59.1 & 0.7 & 100 \\
\hline & Unspecified Torture & 4.3 & 0.4 & 0.4 & 5.8 & 1.3 & 19.1 & 0.7 & 64.2 & 4 & 100 \\
\hline & Head Shaving & 0 & 0 & 0 & 6 & 4 & 34 & 0 & 50 & 6 & 100 \\
\hline & Sexual Abuse & 1.7 & 0 & 1.7 & 5.2 & 0 & 24.1 & 6.9 & 55.2 & 5.2 & 100 \\
\hline \multirow{2}{*}{ Dismissal } & Control Price & 0 & 0 & 0 & 0 & 2.8 & 45.8 & 1.4 & 44.4 & 5.6 & 100 \\
\hline & Destruction & 2.1 & 0 & 0 & 0.3 & 2 & 5.2 & 0.3 & 83.1 & 6.9 & 100 \\
\hline \multirow{6}{*}{ Property } & Extortion & 0 & 0 & 0 & 5 & 1.7 & 20 & 0 & 73.3 & 0 & 100 \\
\hline & Forced Sale & 0.6 & 0 & 0 & 4.9 & 1.8 & 34.1 & 2.4 & 47.6 & 8.5 & 100 \\
\hline & Media Dismissal & 0 & 0 & 0 & 0 & 1.3 & 5.3 & 0 & 93.4 & 0 & 100 \\
\hline & Other Dismissal & 1.2 & 0.6 & 0.3 & 3.5 & 3.5 & 6.7 & 3.2 & 77.2 & 3.8 & 100 \\
\hline & Seizure of Property & 1.3 & 0.1 & 0.4 & 2.6 & 1.3 & 21.7 & 1.1 & 67.5 & 4 & 100 \\
\hline & TOTAL & 5.7 & 0.2 & 0.3 & 3.5 & 1.3 & 16.9 & 1.1 & 67.6 & 3.4 & 100 \\
\hline
\end{tabular}

Figure 2: Human rights violations by categories (Source: Report of the National Reconciliation Commission, October 2004)

Fundamental to all the violations discussed above was the use of repressive measures to enforce economic policies under various military regimes. The history of price controls dates back to 1962 when the Control of Prices Act of 1962 (Act 113) was introduced; suggesting that such policies were not exclusively the feature of military regimes since the first military coup occurred in Ghana in 1966. However, the brutal implementation of price control policies were rampant under military regimes than they were under civilian governments. The National Redemption Council, that toppled the Convention People Party's government of Dr. Kwame Nkrumah, did not only continued this policy but expanded it to include the distribution of scarce consumer goods that were deemed essential for human survival (NRC Report, 2004). The regime passed the Price Control Decree of 1974 (NRCD 305) and the Price Control (Amendment) Decree in 1978 (SMCD 146) that state definite prices for specific consumer goods.

Far from this, it was made an offence for anyone to hoard goods defined as consumer ones. 'Hoarding' was defined to include keeping consumer goods in large quantities with the intention of selling them later at prices above the regime's controlled price. It was also deemed an offence to sell consumer goods outside the official distribution channels stipulated by the military. Yet, the decree did not include how to determine that the person who had stored the goods intend to sell them later and more so above government's determined price. This was left to the imagination of military officers who sparingly applied them depending on the affinity they have with the perpetrator of the crime. The Commercial Houses and Supermarkets (Sale of Specified Goods) Decree in 1976 (SMCD 17) and later amended to the Commercial Houses and Supermarkets Decree in 1976 (SMCD 21) designated specific places for the distribution of essential commodities. None of the designated places was selected to ensure convenience for the ordinary people who desperately needed these goods to buy but it was done to give an economic and personal advantage to members of the military and their relations that partake in this business. Notwithstanding these arrangements and the motive behind them, the military made it an offence for people to openly express dissent or demonstrate against them. A plethora of price control offences and the brutal nature in which the military responded to them led to the development of different terms for 'hoarding' including 'profiteering' and the most common been 'kalabule.'

The military justified the excessiveness regarding price control on economic reality. They argue that goods which were in great demand were in short supply. Though that was the reality at the time, the policy response was not only ill-conceived but also created its own culture in Ghana. In order to ensure efficient and fair distribution of consumer goods at regime designated points, the military leaders devised a 'chit system' by which goods were sold to people who needed them. However, the direct opposite of what was intended occurred since the chits system created a lot of malpractices whereby people who were close associates to high ranking military officers had access to the chits. To make matters worse, people who had access to chits had their own way of issuing them. They select mainly their acquaintances and business associates from whom they could also benefit. The consequence was that goods were often denied to legitimate chit holders who were not close to any person in authority forcing them to buy them at alternate places were the price could be thrice as high as the regime's designated shops and supermarkets. Army officers and citizens who controlled chits became wealthy overnight whiles ordinary citizens suffer in abject poverty. This bred its own promiscuous lifestyles in which young ladies slept with military officers to gain access to chits for goods. In an attempt to 
control these moral decadence and corruption that was creeping into the Ghanaian moral fiber, the military went on a nationwide rampage ceasing perceived hoarded goods and beating people who have allegedly violated the price control measures.

\section{CONSEQUENCE OF HUMAN RGHTS VIOLATIONS ON ViCTIMS}

Regarding economic right violations, the Commission received three categories of petitions: the burning down of markets that serve as source of livelihood to victims; unlawful dismissal from work and confiscation of properties. Many traders perceived as profiteers were arrested, beaten and sometimes even killed. Markets suspected to be housing hoarded goods were burnt to ashes. The AFRC specifically mooted policies aimed at demolishing places were hoarded goods were kept. Pursuant to this idea, many stores and warehouses were torched in the country including the Makola market in Accra, the Tamale market, the Sekondi market, among others. In the national capital for instance, the Makola market (No. 1) which is seen as one of the largest open markets in Africa was looted and burnt down to ashes. In Tamale, the central market was completely burnt down. According to eyewitnesses, the fire broke out on the $8^{\text {th }}$ of February 1982, destroying all the stalls and stores in the market. Following this incident, a Committee was set up by the Regional Administration to investigate the cause of the fire. According to the Committee, the cause of the fire was linked to the fight against price hikes and the hoarding of goods. It further notes that Ghanaians ignored the regime's call on them to reduce the prices of goods and instead created artificial shortages in order to make profit.

However, the report of the Committee attempted to mislead Ghanaians into believing that the burning of the markets and in particular the Tamale one was carried out by the people and not the military. Several citizens across the country who never had an opportunity to be handed down justice for these abuses petitioned the National Reconciliation Commission in relation to this incident. For example, Afi Madonunawo Damesi from Ho notes that in 1982, soldiers under the leadership of Major Ameyibor of the Ho Mortar Regiment seized 600 bags of sugar and 24 cartons of yeast she had imported from Togo through the Aflao border. Similarly, Rose Apedoe from Nii Boye Town in Accra told the Commission about how her goods were seized by soldiers in 1982. She remembered W.O.I Teye as the man who led the operation in which cements, roofing sheets and many others were taken from her. Also Issifu Yakubu from Tamale relates to the Commission how his 45 bags of maize at Zenendo, near Gushiegu were taken from him. These different testimonies across different regions in the country demonstrated the extent to which these abuses were widespread. Victimizations related to price control measures became one of the national narrative around which present human rights abuses are recited.

Closely related to enforcing price control laws was the confiscation of properties and unlawful dismissal of citizens from work by military regime leaders. In some of the military regimes, particularly during the PNDC era, most citizens had their assets taken away from them in a rather arbitrary manner. The rich became target for the unpopular 'one man; one house' policy. ${ }^{\text {iii }}$ For example, Emmanuel Kweku Amissah, a businessman in Accra, relates to the National Reconciliation Commission how his home located at North Labone in Accra, and his two cars (Mercedes Benz and a VW Scirocco) were all confiscated from him during the time of the PNDC. Also, Richard Tetteh Seglah a former lawyer, Member of Parliament and one time PNDC Secretary for the Volta Region in 1986 had his properties confiscated in 1989 when he was relieved of his post as the PNDC Secretary. According to him, three of his homes (H/No. 13 Faana Crescent, Mamprobi, Accra; House at Anloga, and H/No. $29^{\mathrm{A}}$ Achimota Forest, Abelemkpe, Accra) were confiscated by the military. Seglah notes that the PNDC seized those properties because they thought he illegally acquired them when he was appointed PNDC Secretary for the Volta Region. However, the Commission took the position that Seglah acquired those properties prior to his appointment as the PNDC Secretary. Hassan Jebila Mayaki is another victim of the asset confiscation spree that became part of the PNDC regime. According to him, he formed a construction company, Mayakom Limited, with his brother in 1991. Together, they imported the following equipment for the company; Caterpillar Motor Grader, Caterpillar 933, Traxcavator/Loader, Buffalo Springfield Roller \& its Trailer and a Vibro towed type vibratory roller. However, when the equipments arrived at Tema Harbour, they were seized based on orders from the PNDC top hierarchy. Hassan was not given any reason why those equipments were seized neither was he compensated. Several people suffered similar fate and as a result many petitions to the Commission fall within this category of human rights violations. ${ }^{\text {iv }}$

In relation to unlawful dismissal from work, many citizens petitioned the National Reconciliation Commission for justice. It was typical of most military regimes (and some civilian ones like the Progress Party government) where several workers were dismissed via radio broadcast without due regard to their rights as employees. For example, on the $26^{\text {th }}$ and $28^{\text {th }}$ of December 1984 , there were radio and newspaper ${ }^{\mathrm{v}}$ announcements in which 200 people were dismissed from their work. The reason cited for the dismissal was 'disciplinary offences' to which no board of enquiry was set up to investigate and victims were not given the right to defend themselves against those allegations. Apart from these dismissals en masse, individuals were sacked for reasons unknown to them. They were also refused compensation. For example, John Kingsley 
Eduam, an employee of the Ghana Post and Telecommunication Service, was informed on $31^{\text {st }}$ January, 1985 that his name was among those dismissed over the radio on $28^{\text {th }}$ December 1984 . Contrary to the claim by his employers, his name did not appear in that broadcast. All efforts to prove this failed and he was refused compensation. Nathan Kwashie Cheetham, another former employee of the Ghana Post and Telecommunication Service suffered a rather pathetic dismissal from Ghana Airways because he was affected by the $22^{\text {nd }}$ December radio announcement. According to him, he was recommended to Ghana Airways by his former employers and was readily accepted. However, when his new employers (Ghana Airways) realised, after twenty months of working for them, that he was affected by the radio broadcast at his former work, they dismissed him.

Several reasons could be used to explain some of these actions embarked by the military when they were in power. Though some of them were taken with respect to the political environment at the time, it is argued that two possible motives may help explain these actions. These were institutional directives where soldiers on the ground receive direct orders from the political command of the military to carry out certain actions; and personal vendetta where these abuses were not authorized by the state or their superiors but were rather personal vendettas carried out by individuals or groups within the military to settle personal scores (Alidu, 2010). No matter the reasons that inform these actions, it caused many citizens a lot of pain they will never forget and permanently affected others lives. For example, Evelyn Owusu, a Ghanaian student nurse living in the United States, told the NRC about her sad experience during the $31^{\text {st }}$ December 1981 revolution. She petitioned the Commission to demand justice for herself, her brother Kyeremeh Djan, her nephew Atta Boakye and the brother's daughter Abena Yeboah Djan. According to her testimony before the Commission, the brother was one of the leaders of the student union of the Kwame Nkrumah University of Science and Technology which was opposed to the $31^{\text {st }}$ December revolution. Her brother went into exile after he was declared wanted by leaders of the revolution. He later returned to Ghana and sought shelter (together with a friend called Mawuli Goka) at Evelyn's place in Tema, a suburb of Accra. The military raided Evelyn's house, following a tip off on $30^{\text {th }}$ October 1985, and arrested her brother, his friend and Evelyn's nephew Atta Boakye Djan. During the raid, the military allegedly found a sack of weapons in the room and invited Evelyn too for questioning. During their incarceration, Kyeremeh Gyan and Mawuli Goka were allegedly tortured and later executed for treason. However, Evelyn and her nephew, Atta Boakye, were released after several months of detention. As a result of this, Evelyn lost her job and the brother's daughter, Abena Yeboah Djan, dropped out of school. She therefore petitioned the Commission to seek justice for all that had happened to the Djan family.

Another victim, Samuel Kwadwo Boateng, who was a businessman, brings to the fore the extent to which the military could go to create panic and insecurity within the civilian population just to hang on to power. According to Boateng, he had just returned to Ghana from abroad and established a pub where he sold foreign drinks. Then one day soldiers stormed his pub and demanded to see the license with which he was operating the store. Upon showing the license to the military officers, they took it and tore it into pieces. They then packed all the drinks at the store and those he had stockpiled at home and headed to the barracks. He was detained, beaten and subsequently released. He therefore petitioned the Commission to demand some form of compensation for the loss. He said to the Commission:

My lord, after this incident, I was very hard up and so I had to sell my deep freezer and other things to make up for our living. Later I found life unbearable, so I sent my wife and children to the village and I was left alone in Accra... My Lord, all that I want to tell the Commission is that this so-called revolution had made us poor, sick and others have died, and I am pleading with the Commission that if I may be given some reparations for all that I have lost (NRC Transcript, ACC000186) ${ }^{\mathrm{vi}}$.

When asked whether the military deliberately decided to target traders after the coup, Cpl Mathew Adabuga, one of the brains behind the $31^{\text {st }}$ December 1981 revolution, responded:

I must be honest with you. At that time we believed that we could control prices so, a certain amount or order was given that people should try and sell by the prices that the government has given, forgetting that it is not so easy. So, some of the soldiers took the law into their own hands to harass the traders but it was not national (NRC Transcript, ACC00739) vii $^{\text {. }}$

In a follow-up question, one of the Commissioners of the NRC, Mensah-Bonsu, wanted to know why Syrians and Lebanese were also targeted. Adabuga had this to say:

Well it was believed that at that time they were engaged in such acts like buying and selling of gold and diamond and other precious minerals and Riad also had a bone to pick with them that is why he was the brain behind... (NRC Transcript, ACC00739) ${ }^{\text {viii }}$. 
The cases of Evelyn, Samuel and the Lebanese/ Syrians represent a fraction of the general situation in the country at the time. As a result, quite a number of people, especially victims demanded some form of empowerment against future abuse. In response to these demands, the Ghanaian TRC was established to address the injustices committed to these victims. The TRC recommended the establishment of a Reparation and Rehabilitation Fund to help restore some form of dignity to these victims, notwithstanding its position that monetary compensation 'can never restore victims to the status quo ante' (NRC Report, p174). This decision could have been influenced by the fact that monetary reparation is a right of victims of human rights abuses as enshrined in both the 1992 Constitution of Ghana and several other international treaties the country is a signatory to. Indeed, Roht-Arriaza (2004) points out that contrary to popular perception, reparation for victims of human rights abuses is a right and not a favour. The UN Basic Principles and Guidelines on the Right to a Remedy and Reparation for Gross Violations of International Human Rights Law and Serious Violations of International Humanitarian Law, adopted by the United Nations General Assembly Resolution 60/147, clearly states that victims of grave human rights abuses have a right to reparation.

However, not all victims were aware that it is their right to claim compensation for what they have suffered. Some victims among those who knew it was their right to ask for reparation were reluctant to demand it. For example, Kofi, who is the Managing Editor of one of the country's newspapers, acknowledges the abuses he has survived during the country's turbulent times but was not in favour of monetarily compensating for him. He argues that he was "...engaged in a political struggle [and] don't need to be compensated for the wrongs that I get in the course of the struggle" (Interview, 2008). He then posed one of the thorny issues regarding compensation noting, "[W]hat compensation can anybody give me for all the years of imprisonment and so on? (Interview, 2008). Naba, another respondent, concurred the position taken by Kofi arguing that "[Reparation] is a good gesture but never significant enough. [It signifies]... a recognition of the suffering of the victim (Interview, 2008). Reparations to victims took several forms including economic, social and psychological. In economic terms, some identifiable victims of human right violations who testified before the National Reconciliation Commission were paid some monetary compensation. The psychological and social reforms took the form of cathartic experience as victims ventilate their grievances for the first time. Counseling was provided to those who need them and the corpses of tortured victims were exhumed for befitting reburial. Considering the large number of people who demanded compensation for human rights violations committed against them, it became impossible to reparate all of them.

Out of the over 4000 victims who testified before the Commission, only 2,514 were selected for reparation and about 2,117 were eligible for monetary reparation (Alidu, 2010). The remaining 397 received other forms of reparation including reinstatement to their previous jobs and repossession of properties that were ceased (Alidu, 2010). The government of Ghana, following the findings of the Commission provided a total of GHC 530,000 to be used in paying victims of human rights abuses that qualified for monetary reparation. Regarding de-confiscation of properties ceased by the military, the Daily Graphic $(2008)^{\mathrm{ix}}$ reported that several victims, including four past Heads of States, had their assets restored to them. The Confiscated Assets Committee, the Restoration of Assets Committee and the Attorney-General's office released the names of 137 beneficiaries of the assets de-confiscation programme including former Heads of States Kwame Nkrumah, General A.A. Afrifa, General I.K. Achaempong and General F.W.K. Akuffo. Also included the lists were Dr Matthew N. Tetteh, who owns 34 houses located at Dansoman Exhibition Site, Adenta Housing Estates, Tema and other parts of Accra; Krobo Edusei and Dr E. Ayeh Kumi who both had 13 houses located at Accra, Tema and the Ashanti Region; and J.K. Siaw with 8 houses in Accra. Even though this policy stemming from the recommendation of the National Reconciliation Commission was not spared of party politics, the reparation programme was one of the most successful attempts at giving justice to victims of economic and social human rights violations in the country since independence.

Besides these three categories that were captured by the work of the Commission, academics have identified corruption as a serious economic right violation that needs to be addressed during transitions. Carranza (2008) for example notes that the work of truth commissions and many other transitional justice programs are meant to address civil and political rights violations and not with violations of economic and social rights that include large-scale corruption. She draws the nexus between corruption and continued human rights violations, arguing that the graft of corrupt leaders reinforce their economic wherewithal to perpetuate more violations. In Ghana, testimonies before the truth commission suggest that leaders of military regimes that painstakingly tried to enforce austerity lifestyles for majority of the citizens lived luxurious lifestyles themselves. Apart from looting state resources to finance personal expensive lifestyles and that of their close associates, military leaders also steal state money to perpetuate their stay in power by creating an atmosphere of fear and intimidation. Throughout the four occasions that Ghana has been under military rule, these features were manifest. This practice has engendered corruption in the country with huge financial consequences.

Ghana has not experienced military coup after the 1992 democratic transition but it has been fighting corruption, graft at the executive level and gratuitous abuse of state resources by just a few that control state 
power. Politicians who promise to fight corruption are the same people who corrupt the citizenry through acts such as vote buying, selling state assets to themselves at undervalued prices, subverting the public tender process for the award of contracts, among several others. The World Bank, Transparency International and the Centre for Democratic Development-Ghana have all warned that corruption is the bane to Ghana's successful economic development. Various governments since the Kufour-led NPP administration have instituted measures to fight graft. Under the NPP the Whistleblower Act was passed to enable people report acts of corruption at their work places. Yet, virtually nothing is done after the act is reported. When the main opposition NDC at the time complained, the President fired back noting that corruption started from Adam and cannot be wiped away so easily. When the NDC came back to power in 2008, they resourced and legally empowered the Serious Fraud Office (SFO) the main state institution for investigating and fighting graft. It was given the power of entry, search and prosecution and renamed the Economic and Organized Crime Organization (EOCO). Besides EOCO, the Commission on Human Rights and Administrative Justice (CHRAJ) is another state institution invested with the power to fight economic and social rights violations.

However, both CHRAJ and EOCO have some impediments that will affect their ability to successfully fight corruption against members of the Executive. As state institutions, the Executive has control over them in terms of the allocation of funds for their activities which may need the approval of the Minister of Finance. Unlike EOCO, CHRAJ has only the constitutional authority to investigate human rights violations, the power of subpoena and recommendations but not the authority to prosecute. The power of prosecution is the sole decision of the Executive - the Attorney-General. Therefore the general decision by most truth commissions and as noted by Carranza (2008) to leave economic rights violations for state institutions to address whiles transitional justice programs address political and civil rights is just to entrench impunity and economic graft.

\section{RESPONSES TO HUMAN RightS VIOLATIONS}

The National Reconciliation Commission has been the most comprehensive attempt at addressing the plethora of human rights violations in the country besides several commissions of inquiries and other piecemeal measures. The National Reconciliation Commission Act (Act 611) was controversially passed by mainly NPP members of Parliament when their NDC counterparts walked out of parliament over disagreements on some of the provisions. Generally, the Commission was established to promote reconciliation in Ghana and make recommendations for redress, most of the human rights violations committed in the country. Section 4 (a-e) of Act 611 empowered the Commission to investigate human rights abuses related to killings, abductions, disappearances, detentions, torture, ill-treatment and seizure of properties during past military regimes in the country; investigate the causes and contexts within which those abuses occurred; identify perpetrators and victims of such abuses; make appropriate recommendations for redressing such abuses; and, make the work of the Commission a source of public education. The Commission was established to address the culture of impunity that has crept into the Ghanaian political discourse. Ghana experienced four successful coups in 1966, 1972, 1979 and 1981 and several attempted ones in which extensive human rights violations occurred. Besides human rights violations occasioned by military coups, there are recurrent ethnic and chieftaincy disputes fought across the country. Though these conflicts did not fall under the mandate of the Commission, they nonetheless contributed to a plethora of issues that brought about the general level of mistrust and hatred that have characterized the Ghanaian state. However, the most significant factor that necessitated the establishment of the Commission is the serious legal impediments in bringing former military leaders that superintend these abuses to accountability. Entrenched indemnity clauses were included in the 1992 Constitution that brought about the country's democratic transition in 1992 and in part reads as follows:

For the avoidance of doubt, it is declared that no executive, legislative or judicial action taken or purported to have been taken by the Provisional National Defence Council or the Armed Forces Revolutionary Council or a member of the Provisional National Defence Council or the Armed Forces Revolutionary Council shall be questioned in any proceedings whatsoever and, accordingly, it shall not be lawful for any court or other tribunal to make any order or grant any remedy or relief in respect of any such act (Parliamentary Debates on the Bill of the NRC, 2001).

This provision has not only indemnified members of both the AFRC and the PNDC for the coups they staged, but it also exonerate them from any legal liability for the excesses committed during the revolution (Alidu, 2010). The transitional provision, as it is commonly known in Ghana, is an entrenched one making it difficult to repeal. According to Ameh (2006) it could only be amended after a referendum in which $40 \%$ of all eligible voters must vote, with $75 \%$ of them supporting the amendment. The logic behind this complex procedure is to discourage any attempt aimed at repealing this indemnity clause since it takes a very popular government to attain a 75\% majority vote in a referendum. This obstacle prompted the former Ghanaian Attorney-General and Minister of Justice in 2001, Nana Akuffo-Addo, during the Parliamentary debate of the NRC Bill to argue that 
'except for the narrow, limited remit [of a truth commission] there appears to be no legal avenues to get redress, seek compensation or impose any sanction for any wrongdoer or violator of human rights $(2001)^{\mathrm{xi}}$. This therefore leaves a limited remit within which accountability may be implemented, hence the establishment of the reconciliation commission.

The Commission began public hearings on $14^{\text {th }}$ January 2003 at the Old Parliament House in Accra and then continued this exercise throughout the country over a period of 18 months. Witnesses were allowed to be heard in camera when testifying on issues relating to national security and also in cases that could expose them to danger. The Commission heard cases from over 2000 victims and about 79 perpetrators, which were drawn from over 4000 written petitions to the Commission (NRC Report, 2004). The Commission finds that majority of the victims (89\%) that petitioned it demanded compensation for their sufferings; $29.2 \%$ sought the truth about what has happened to them, and only $6.4 \%$ demanded justice. The work of the Commission led to the payment of monetary compensation to selected victims. Indeed, this has been the most visible policy implemented following the Commission's work. Other recommendations including a public apology from the President of Ghana to victims, institutional reforms and the inculcation of human rights guide in the educational curriculum have not been implemented.

\section{CONCLUSION}

The paper examines price control policies in Ghana as an example of economic human rights violations during the country's troubled times. In almost all the military coups that occurred in the country, economic mismanagement and corruption were the most common reasons the military gave to justify them. Also, victims who petitioned the NRC for justice following human rights violations directed at them generally quantified their loss in economic terms.

The Ghanaian case supplements the discussion of the literature in the last few years about the extent to which transitional justice measures have neglected economic and social violations. The National Reconciliation Commission established in Ghana in 2002 sought to investigate large-scale human rights violations of physical nature (such as beatings, torture, abductions, forced displacement, disappearance, etc) neglecting the nonphysical violations (such as economic rights, social rights and corruption). This action reinforces the historical notion in transitional justice that economic and social rights, even when they are addressed, provide a context in which political and civil rights are perpetrated (Sharp, 2011). It is part of international practice that countries learn from others' good policy experiences. In the history of transitional justice processes, pioneer countries have tended to investigate political and civil rights violations, relegating to the background social and economic rights. Countries that initiated similar programs later in their history follow the footsteps of these pioneer ones, thus, repeating the same mistakes they have made. Several reasons explain the decision in Ghana and in many other countries that undergone similar transitional process, whether deliberate or not, to focus on political and civil rights. First, political and civil rights are not only seen to be more justiciable than economic and social rights but also it is believed to be more susceptible to redress via any of the toolkits under transitional justice (Carranza, 2008).

In Ghana, it was easier to examine political detentions, torture and disappearance and decides who gets what compensation based on the number of years spent on detention than to study corruption and how many people were unlawfully dismissed from their work. Carranza (2008) notes that of the 34 truth commissions established between 1974 and 2004, only three expressly engaged with economic rights violations whilst the rest have left such responsibility to domestic state institutions or bundled them under the broader banner of future development programs. Domestic accountability mechanisms find it difficult to address economic rights violations, especially those committed by the Executive because of the relationship that exists between them. This has led to entrenched economic crimes even in peace times as there were during repressive regimes. A point of departure is therefore needed. Perhaps, Sharp's (2011) suggestion that the concept of transitional justice needs reorientation and reconceptualization is necessary. According to Sharp, transitional justice, should be defined to embrace broader "positive peace" rather than the narrow conception of moving to democracy and the rule of law. This way of viewing the work of truth commissions, the most popular of all the transitional justice tools, would enable investigation into economic and social crimes more significant.

\section{Acknowledgements}

I acknowledge the contribution of several colleagues who have read through this paper, especially Mr. Aweisu Braimah and the anonymous reviewers who also provided valuable contributions.

\section{REFERENCES}

[1]. Aburge, C. (2001) Actors, Participation and Ownership, Washington: The World Bank

[2]. Alidu, S. et al. 'Truths' and 'Re-Imaging' in the Reconciliation Process' Journal of Peace Review, 21: 135-142, 2009 
[3]. Alidu, S. Achieving Reconciliation in Commission: the role of the Ghana National Reconciliation Commission, Unpublished thesis submitted to Leeds Metropolitan University for the award of a Doctor of Philosophy in Peace and Development Studies, 2010

[4]. Ameh, R. Doing Justice after Conflict: The Case for Ghana's National Reconciliation Commission', Canadian Journal of Law and Society, 21(1) 85-109, $2006 a$

[5]. Ameh, R. Uncovering Truth: Ghana's National Reconciliation Commission Excavation of Past Human Rights Abuses'. Contemporary Justice Review, 9(4), $2006 b$

[6]. Attafuah, K. (2004) An Overview of the Ghana National Reconciliation Commission and its Relationship with the Courts, Criminal Law Forum, 15(1-2), 125-134, 2004

[7]. Carranza, Ruben. Plunder and Pain: Should Transitional Justice Engage with Corruption and Economic Crimes? International Journal of Transitional Justice, 2(310 -330), 2008

[8]. Church, M. et al. Participation, Relationship and Dynamic Change; New Thinking on Evaluating the Work of International Networks" Development Planning Unit, UCL, Working paper No. 121, 2002

[9]. CIVICUS. Legal Principles for Citizen Participation: towards a Legal Framework for Civil Society Organizations, Washington DC: CIVICUS, 1997

[10]. Cole, W.M. Strong Walk and Cheap Talk: The Effect of the International Covenant of Economic, Social, and Cultural Rights on Policies and Practices, Journal of Social Force, 91(4), 2013

[11]. Daily Graphic 'Four Former Heads of State, 133 others Get Back Assets', Wednesday, 22 ${ }^{\text {nd }}$ October 2008

[12]. DeMeritt, J.H.R and Young, J.K. A Political Economy of Human Rights: Oil, Natural Gas, and State Incentives to Repress, Journal of Conflict Management and Peace Science, 30(3), 2013

[13]. Fariss, C.J. and Schnakenberg, K.E. Measuring Mutual Dependence between State Repressive Actions, Journal of Conflict Resolution, 57(4), 2013

[14]. Gyimah-Boadi, E. National Reconciliation Commission in Ghana: Prospects and Challenges, CDD-Briefing Paper, 4 (1), 2002

[15]. Gyimah-Boadi, E. Confronting the Legacy of Human Rights Abuses in Africa: Lessons from Ghana', Unpublished Paper, Delivered at the International Conference on Transitional Justice in Africa: Future Directions, organized by ICTJ, Bellagio, March 25 - 29, 2004.

[16]. Keith, L. C. The United Nations International Covenant on Civil and Political Rights: Does It Make a Difference in Human Rights Behavior?, Journal of Peace Research, 50(4), 1999

[17]. Republic of Ghana (2004) The Rational Reconciliation http://www.ghana.gov.gh/ghana/national_reconciliation_commission_report.jsp_0 (accessed on 12/05/2009)

[18]. Republic of Ghana, (2001) Parliamentary Debates, Fourth Series, 30 (21, 22, 23, and 24), Accra

[19]. Roht-Arriaza, N. Reparation Decisions and Dilemmas', Hastings International and Comparative Law Review, 27(2), 2004, 157-219

[20]. Sharp, D.N. Addressing Economic Violence in Times of Transition: Towards a Positive Peace Paradigm for Transitional Justice, Fordham International Law Journal, 35 (3), 2011 